Document downloaded from:

http://hdl.handle.net/10251/33332

This paper must be cited as:

Soares Costa, RM.; Martinez-Capel, F.; Muñoz Mas, R.; Alcaraz-Hernández, JD.; GarófanoGómez, V. (2012). Habitat suitability modelling at mesohabitat scale and effects of dam operation on the endangered Júcar nase, Parachondrostoma arrigonis (River Cabriel, Spain). River Research and Applications. 28(6):740-752. doi:10.1002/rra.1598.

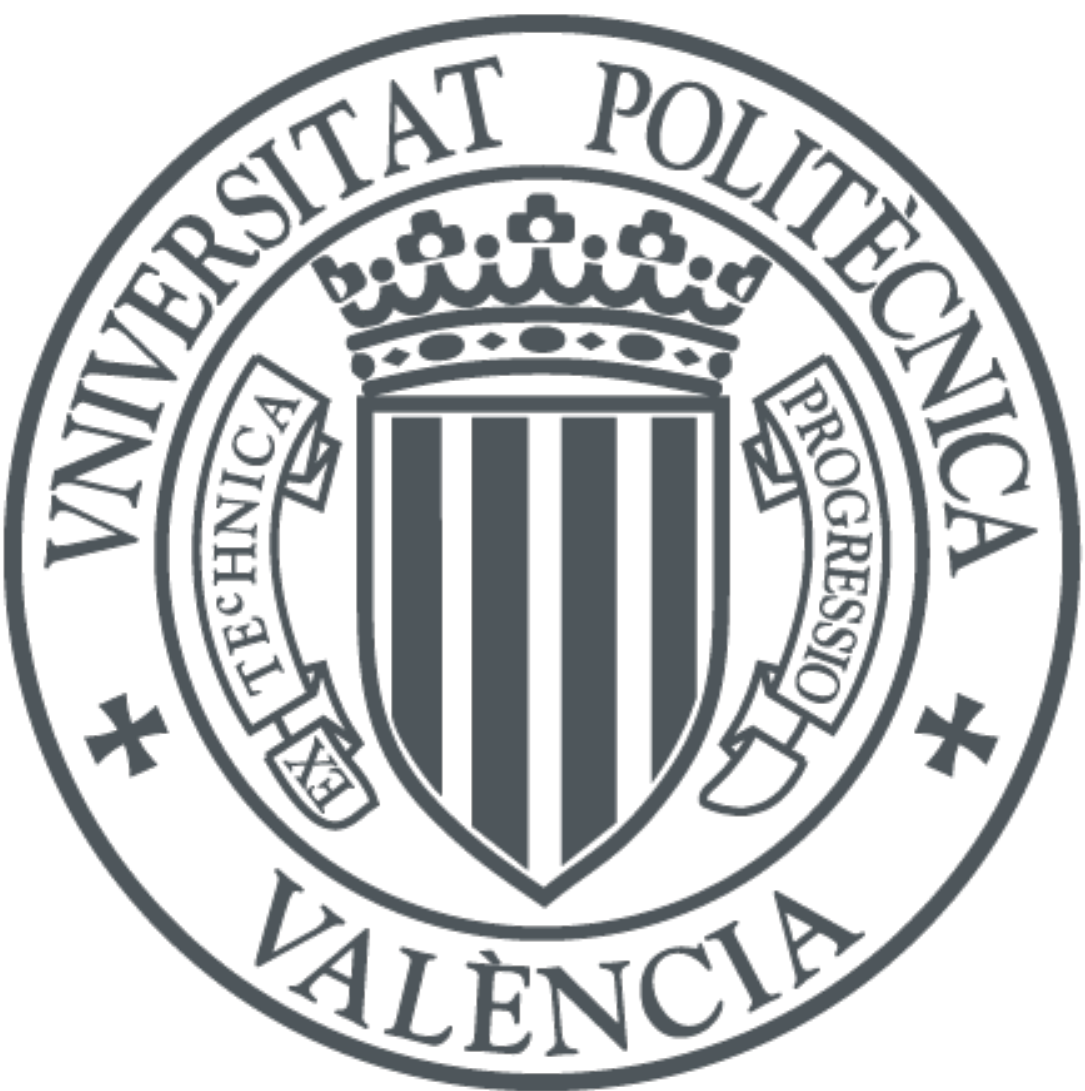

The final publication is available at

http://dx.doi.org/10.1002/rra.1598

Copyright Wiley-Blackwell

Additional Information 
This is a pre-copyedited, author-produced PDF version following peer review of this article, which has been published in definitive publisher-authenticated form at:

http://onlinelibrary.wiley.com/doi/10.1002/rra.1598/abstract

Published in: River Research and Applications. Volume 28, Issue 6, pages 740-752, July 2012.

\title{
Habitat suitability models and effects of dam operation on the endangered Júcar nase, Parachondrostoma arrigonis (river Cabriel, Spain)
}

\author{
Costa, R. ${ }^{a}$, Martinez-Capel, F. a, Muñoz-Mas,R. ${ }^{\text {a }}$, Alcaraz-Hernández , J.D. ', Garófano-Gómez, V. ${ }^{\text {a }}$ \\ ${ }^{a}$ Institut d'Investigació per a la Gestió Integrada de Zones Costaneres, Universitat Politècnica de València \\ Calle Paranimf nº 1 , Grao de Gandia 46730, Valencia, Spain \\ Corresponding autor: R. Costa, rmanuelc@gmail.com
}

\begin{abstract}
The presence of large dams affects habitat availability, often regarded as the primary factor that limits population and community recovery in rivers. Habitat degradation has reduced the complexity and connectivity of the Mediterranean streams in Spain. These changes have diminished the historical range of the endangered Júcar nase, Parachondrostoma arrigonis (Steindachner, 1866), isolated the populations of this species, and probably contributed to its risk of extinction. In the Júcar River basin (Spain), where this fish is endemic, the populations are mainly in the river Cabriel, which is fragmented in two segments by the large dam of Contreras. In this river, the availability of microhabitats and hydromorphological units (HMU), and their relation to the flow regime were studied from 2006 to 2008 . The physical characteristics by hydromorphological units were compared among the 8 study sites, upstream and downstream the large dam. The abundance of Júcar nase was related to the HMU type, and a multivariate model of fish abundance was developed with GAMs in the regulated sites, for small and large fish separately. Univariate microhabitat suitability curves were made (for depth, velocity, substrate and cover), and both kind of models allow the application of different tools and methodologies for environmental flow assessments, at different scales. Based on the multivariate model, we used hydraulic simulation to evaluate the potential importance of dam operation for the fish abundance, taking the natural flow regime as the reference. Finally, the potential effects of mitigation measures, such as two alternatives of environmental-friendly flow regimes, were evaluated with the same model at the scale of HMU, in the regulated segment below the large dam. The results support the proposal of management actions, such as the implementation of an environmental flow regime, with anticipated releases more coincident with the natural flow regime (previous to the fish spawning) and therefore smaller discharges during the summer.
\end{abstract}

Keywords: Mediterranean rivers, dam effects, Júcar nase, habitat suitability, hydro-morphological units, microhabitat

\section{INTRODUCTION}

The increasing human demands upon water resources and consequent flow regulations may have negative consequences on the environment (Fette, 2007) such as the disruption of longitudinal linkages within streams that impede the lateral movement of fauna and decrease the availability and diversity of habitats (Baeza et al., 2003; Brainwood, 2008). River ecological changes caused by physical responses to flow variation, include loss of stable aquatic and riparian habitat, changes in sediment dynamics, water temperature and flow velocity and reductions in wetted area and aquatic habitat diversity (Zimmerman, 2009). The water demands and the growing concerns about environmental change have focused on the need to determine and protect flows to sustain stream ecosystems (Petts et al., 1999). This involves not only minimum flows to meet the critical habitat 
requirements of a target species, but also the range of flows required to sustain the functioning of these ecosystems, including riparian and floodplain areas (Petts and Maddock, 1996).

Natural river systems exhibit an enormous variety of physical and biological forms and processes. Understanding, measuring, and predicting these forms and processes has been a central concern of those who study, manage, and use river systems (Wang et al., 2006). Managers and researchers need to be able to order this variability so that they can prioritize conservation efforts, and be confident about extrapolating research or management outcomes to functionally similar systems (Thomson et al., 2004). The first approaches to classify the river systems into hydro-morphological units or mesohabitats (hereafter HMUs), e.g. pools, runs, riffles, cascades, floodplains, were made during the 80s and 90s (Bisson et al., 1982; Frissel et al., 1986; Hankin and Reeves, 1988; Hawkins et al., 1993). The HMU consists of a mosaic of several, perhaps different, microhabitats (Hill et al., 2008). Although the effect of habitat complexity on fish assemblages has been well studied (e.g., Jungwirth et al., 2000; Schiemer et al., 2003; Smokorowski and Pratt, 2007), quantitative description and mathematical modeling has gained focus only recently (e.g., Jungwirth et al., 2000; Fette et al., 2007; Schwartz and Herricks, 2008). Habitat degradation associated to river regulation has reduced the complexity and connectivity of the Mediterranean streams in Spain (García de Jalón, 1987).

Mediterranean river fish communities are dominated by cyprinids (Ferreira et al., 2007) with a high number of endemic species with a reduced distribution range compared with elsewhere in Europe (Granado-Lorencio, 1996; Doadrio, 2001). However, few studies have focused on the habitat use of some endemic species in the Iberian Peninsula (e.g. Grossman and De Sostoa 1994a, b; Magalhães et al., 2002; Martínez-Capel et al., 2009). The target species of this study is one of those Iberian endemisms, the Júcar nase, Parachondrostoma arrigonis (Steindachner, 1866) and is considered in risk of extinction (IUCN,2001). With a low commercial value, the population of Júcar nase is restricted to the Comunidad Valenciana and Castilla La Mancha (both in Spain) and is believed to be experiencing a decline over the last 20 years (Doadrio, 2003). The ecological importance of these populations resides in its adaptation to the Mediterranean conditions with high fluctuations of both intra and inter-annual flow rates (Sabater et al., 1992; Vidal-Abarca et al., 1992). Nevertheless and probably due to the low commercial and fishing value of this species, the information about habitat selection, feeding behaviour and reproduction season is scarce.

Our study examined physical habitat characteristics and their relation with Júcar nase assemblage in the river Cabriel, up and downstream the large dam of Contreras (Spain), where dam operation can affect the fish conservation. Specifically, we addressed the following issues: (i) the differences among study sites based on the physical characteristics of HMUs, (ii) the selection of habitat by the fish, at microhabitat and HMU scale, iii) the relevance of dam operation for the fish population, taking the natural flow regime as the reference, and the potential effects of mitigation measures, such as two alternatives of environmental-friendly flow regimes, for the species conservation.

\section{METHODS}

\section{Study sites and target species}

This study was carried out in the Júcar River Basin, one of the pilot basins for the implementation of the Water Framework Directive, located in the provinces of Valencia, Cuenca and Albacete (East Spain). With a typical Mediterranean climate, this basin has a drainage area of $22,123 \mathrm{~km}^{2}$, and three major rivers, Júcar, Cabriel and Magro. The Júcar River is $511 \mathrm{~km}$ long emptying directly into the Mediterranean Sea, with an average gradient of $3.37 \mathrm{~m} / \mathrm{km}$; the sustainable populations of the target species live in the rivers Cabriel and Magro, tributaries of the Jucar River, being 220 and 130 $\mathrm{km}$ long respectively. This study focused on the most relevant populations, in the Cabriel, where 8 study sites (4 down and 4 upstream the large dam of Contreras) were selected. According to budget 
constraints, the sampling sites were minimum $1 \mathrm{~km}$ long (usually longer to survey complete HMUs) and the habitat and population assessment was done during spring and summer of 2006, 2007, 2008 (Fig. 1); the habitat survey was done in the situation of low flow in each site. These sites represent the river attributes in different hydro-morphological conditions, as well as fish communities. Four 4 sites not regulated (upstream of the large dam) were located upstream (2) and downstream of a small weir that separates fish populations with and without exotic fish species. Downstream of the large dam, the fish community includes exotic species anywhere, and the 4 sites represent different hydro-morphological conditions, because downstream of each site there is a tributary with a relevant contribution of watershed area, which determines the potential mitigation of the flow regulation effects. Downstream of the site C5, the most affected by flow regulation, a tributary and several springs contribute to the stream flow. During the survey period (low flows), the mean flow (of the 3 years) in the sites upstream, named as C1, C2, C3, C4 (in order downstream), was 1.30, $2.27,2.08$, and $3.95 \mathrm{~m}^{3} \mathrm{~s}^{-1}$, respectively; in the regulated sites, i.e. C5, C6, C7, C8, it was 0.47, 3.61, 5.20 , and $5.07 \mathrm{~m}^{3} \mathrm{~s}^{-1}$, respectively.

The Júcar nase (Parachondrostoma arrigonis, Steindachner 1866) is a medium-sized fish that is characterized by having an inferior sub-terminal mouth without barbells and with a corneous lip; it feeds on algae and invertebrates by scraping the substrate. It is gregarious, and spawning occurs in the upper reaches of the rivers during spring. For the IUCN (IUCN, 2001) and the Valencia regional government, the Júcar nase is considered in risk of extinction, and the Spanish government classified it as vulnerable because of its drastic population decrease. The population declines have been attributed to water pollution, habitat destruction, introduction of exotic fish predators and hybridization with the introduced Iberian nase (Pseudocondrostoma polylepis, Steindachner 1866) (Elvira, 1995; Elvira and Almodovar, 2008).
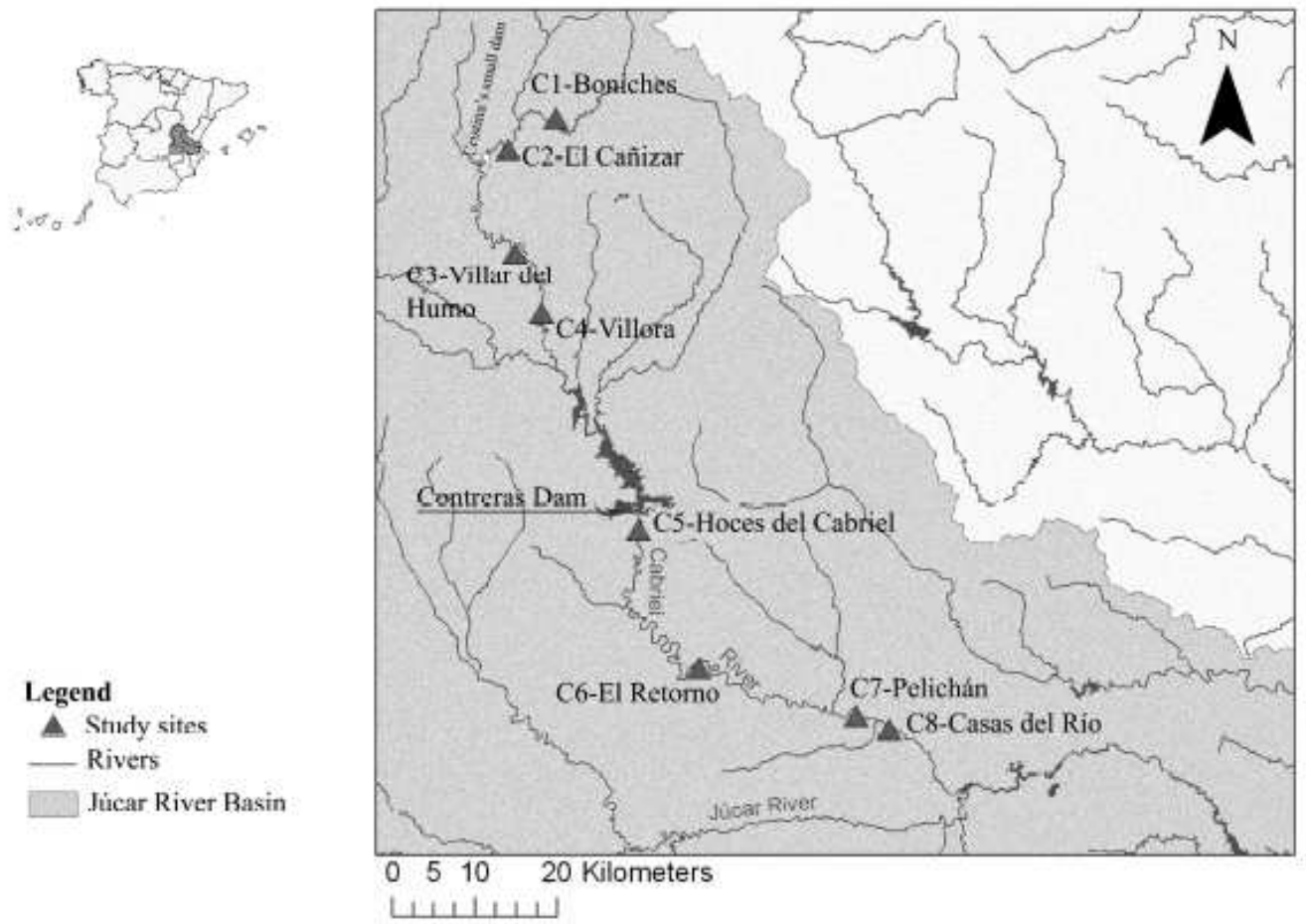

Fiqure 1. Location of the 8 survey sites on the river Cabriel (Júcar River Basin - East Spain) during the 3 years of study. 
In every site the HMUs were classified into pools, glides, riffles, rapids and runs, once during the year campaign. The sites always comprised complete HMUs, usually over the minimum of $1000 \mathrm{~m}$ long. Downstream of the large dam, the ranges were 0.4-6.0 $\mathrm{m}^{3} \mathrm{~s}^{-1}$ in all sites and survey years. For each HMU these habitat variables were taken, length $(\mathrm{m})$, mean width $(\mathrm{m})$, mean and maximum depth $(\mathrm{m})$, and types of substrate in percentages with this typology, bedrock, large boulders (>1024 $\mathrm{mm})$, boulders $(256-1024 \mathrm{~mm})$, cobbles $(64-256 \mathrm{~mm})$, gravel $(8-64 \mathrm{~mm})$, fine gravel $(2-8 \mathrm{~mm})$, sand $(62 \mu \mathrm{m}-2 \mathrm{~mm})$, and silt $(<62 \mu \mathrm{m})$. In addition, habitat complexity was assessed with these variables, area of backwaters by the banks (associated to entering tributaries, in $\mathrm{m}^{-2}$ ), undercut banks covered with water at low flow (in percentage of site's length, average of both banks), pocketwaters by boulders/large boulders $\left(\mathrm{m}^{-2}\right)$, number of boulders and large boulders, quiet waters associated to substrate along banks $\left(\mathrm{m}^{-2}\right)$, quiet waters associated to vegetation along banks $\left(\mathrm{m}^{-2}\right)$, fine sediment covering $(\%)$ and shade $(\%)$. The ranges of survey flow upstream of the dam were $0.4-2.7 \mathrm{~m}^{3} \mathrm{~s}^{-1}$ in 2006, 0.6-3.4 $\mathrm{m}^{3} \mathrm{~s}^{-1}$ in 2007 , and $2.7-5.5 \mathrm{~m}^{3} \mathrm{~s}^{-1}$ in 2008 .

A sub-sample of HMUs was selected for the study of microhabitat use, during spring and summer in the regulated sites; we followed standard procedures to apply the snorkelling technique (Heggenes et al., 1990) during daylight hours, with the equal effort sampling approach (Bovee $e t$ al., 1998). Júcar nase observations were split in two length classes: fry or small $(<10 \mathrm{~cm})$ and juvenile/adult or large fish $(>10 \mathrm{~cm})$. During the snorkelling, upon sighting a fish, a school or shoal of fish, the observer recorded the size class, number of fish, and number of marker in the fish position. When a fish or shoal was disturbed, no data were recorded. After the snorkelling was completed, water depth (D), mean water column velocity $\left(\mathrm{Vm}, \mathrm{ms}^{-1}\right)$, dominant substrate type (S) and cover $(\mathrm{C})$ were recorded. The substrate types were as stated above, and cover types were no cover, undercut banks, roots, boulders, vegetation, shadow, wood debris and others. Microhabitat availability was randomly sampled along transects in the same HMUs to register the heterogeneity of habitat conditions in terms of D, Vm, S and C (Bovee et al., 1998).

To develop a habitat suitability model at the scale of HMUs, Júcar nase abundance was estimated by HMUs, in the whole 8 sites and 3 years. The fish were counted by snorkelling to avoid any damage to this endangered species; two divers made the underwater counts in 3 independent passes, throughout each of the habitats units in the study sites.

The relevance of dam operation for the fish population and the potential effects of mitigation measures were evaluated where flow regulation was more important, site C5 below the dam. The hydraulic modelling was necessary to estimate the variation of habitat characteristics with flow. In 2008, a subsample of HMUs (hereafter simulation site) was selected within C5 to represent the hydraulic conditions, because budget restrictions did not allow the hydraulic simulation of the whole C5, $1124 \mathrm{~m}$ long (average length for the 3 years). This subsample included the HMU types present in the whole C5; specifically, significant differences were tested for mean depth and mean width, between the simulation site and C5, with the non-parametric test of Kolmogorov-Smirnov. The test demonstrated that the simulation site was representative, because there was no significant difference for the dataset over the 3 years (width, $\mathrm{p}=0.124$; depth $\mathrm{p}=1.000$ ). During the 3 surveys the stream flow was very stable due to dam operation (range of $0.458-0.552 \mathrm{~m}^{3} \mathrm{~s}^{-1}$ ). The simulation site comprised a segment $219.8 \mathrm{~m}$ long; the cross-sections were located to record topography and water surface elevation, where the water surface profile had a relevant change and in transitions between HMUs. The water surface elevations were surveyed for 3 flows, 0.570, 5.957 and 13.930 $\mathrm{m}^{3} \mathrm{~s}^{-1}$; these values covered the range of data required to simulate the hydraulics in natural and regulated flow regimes. The survey followed the standards for 1-dimension physical habitat simulation (Bovee, 1998), in order to represent the physical habitat characteristics and to make hydraulic simulation based on accurate rating curves of each transect. 
170

171

172

173

174

175

176

177

178

179

180

181

182

183

184

185

186

187

188

189

190

191

192

193

194

195

196

197

198

199

200

201

202

203

204

205

206

207

208

209

210

211

212

213

214

215

The differences among study sites were evaluated based on the physical characteristics and variability recorded by HMUs. The similarity-based graphical and testing methods developed by Van Sickle (1997) were used; however, instead of similarities we used dissimilarity (distance) following the methods of EnvClass (Snelder et al., 2009), in the statistical package $\mathrm{R}$ ( $\mathrm{R}$ Development Core Team, 2008). As a measure of dissimilarity, Bray-Curtis distance was calculated for each class or site (i.e., all data of a study site); therefore, a class comprises the spatial variability of the different HMUs, and also the variability of the 3 field campaigns. For the 450 HMUs sampled (2006-2008), such multivariate distance was calculated with the variables specified in field methods, and water surface area. The results were shown in a dendrogram or tree of dissimilarity for the 8 study sites; this plot shows the vertical line (trunk) that indicates (in axis at the bottom) the mean distance between-sites $(\bar{B})$, representing the homogeneity and stability of habitat characteristics over the 8 study sites. Each site shows a horizontal line (branch) which length is the mean distance within-site $\left(\bar{W}_{i}\right)$, i.e., the mean distance between pairs of objects (HMUs) within the site (it can be larger than $\bar{B}$, to the right of the tree, or smaller, branches to the left side). A larger difference $\bar{B}-\bar{W}_{i}$, i.e., a longer branch to the left side, indicates a more robust classification of a site in relation to others. Branches to the right side indicate less robust classification, i.e., the differences among HMUs in the site are so important as the differences among HMUs of different sites. To complement this evaluation of differences among sites, a Multidimensional Scaling (MDS) was made using Bray-Curtis distance.

Fish abundance was estimated with the algorithm developed for the 3 counts method (Robson and Whitlock, 1964). A box-plot was made to visualize Júcar nase abundance by HMU type, in the not regulated versus regulated sites. The difference between these 2 groups of sites was tested with the Mann-Whitney pairwise test $(\alpha=0.05)$, separately by HMU.

In order to allow future assessments of habitat suitability and environmental flow studies, with different tools and methods, habitat suitability models were developed at the scale of microhabitat and HMUs in the regulated sites, given the importance of this endangered fish. We generated, at microhabitat scale, habitat suitability curves, and at HMUs scale a multivariate habitat suitability model which predicts fish density. Regarding microhabitat use, data were summarized in frequency histograms, separately for small and large fish, for each microhabitat variable independently. Smooth curves were produced to avoid gaps due to missing data in some intervals, with the software HabitatPref (I.G. Jowett (C) 2005); these curves, based on equal effort sampling, were normalized between 0 and 1 , as standard habitat suitability curves for physical habitat simulation (Bovee, 1998).

For the multivariate habitat suitability model, based on variables measured at HMUs, the associations between Júcar Nase abundance (small and large, independently, in number of fish per HMU) and a list of the main physical variables were examined using Spearman rank correlation (significant correlations were accepted at $\mathrm{p}<0.05$ ). We selected habitat variables that can be simulated for different flows, i.e. mean and maximum depth, mean width and substrate index, as well as others of importance for the fish (Costa et al., 2010): flow, mean velocity (estimated as flow divided by mean cross-section area at each HMU), area of backwaters $\left(\mathrm{m}^{2}\right)$, and proportion of undercut banks. The substrate composition was converted into a single index by summing weighted percentages of each substrate type (Mouton et al., 2011), as follows, s $=0.08 \times$ bedrock $+0.07 \times$ boulder $+0.06 \times$ cobble $+0.05 \times$ gravel $+0.04 \times$ fine gravel $+0.03 \times$ sand. The rest of habitat features measured in the field were not selected because a low number of variables offer more possibilities to apply the model in other rivers with a restricted budget, and the other variables of less importance would be complex to simulate with flow variation; backwaters and undercut banks 
were considered important based on previous data exploration and the experience of the divers in the field.

Generalized Additive Models (GAMs) were developed to predict fish density (CPUE) in function of habitat variables, with the program HabitatPref (I.G. Jowett (C 2005). GAMs can analyse non-linear relationships between species distribution and environmental variables, and take into account the correlation and interactions among variables (Ahmadi-Nedushan et al., 2006; Jowett et al., 2007). The model was a log-linear GAM, assuming that the response variable follows a Poisson distribution (Jowett et al., 2007), with 3 degrees of freedom. Two different procedures were used, with forward selection and backward elimination of variables (for small and large fish, independently). Firstly, a GAM was obtained using a forward stepwise procedure, adding variables one by one based on the Spearman rank correlations coefficients (starting with the main predictor variable of fish CPUE). To evaluate GAM's performance we used the adjusted $\mathrm{R}^{2}$ and the Akaike Information Criterion (AIC, Akaike, 1974). To avoid the effect of collinearity in the models, Spearman rank correlation coefficient was calculated for the variables pairwise; then, variables with significant correlations were not included in the same model, and alternative GAMs were evaluated with the different variables. Secondly, the 8 variables aforementioned were introduced for a GAM, and they were discarded one by one stepwise backward, according to the F value of an F-ratio test, retaining only the variables with $\mathrm{P}<0.05$; this F-ratio test evaluate the non-linearity of each variable, by comparing the residual deviance of models with linear $(\mathrm{df}>1)$ and linear $(\mathrm{df}=1)$ terms (Jowett et al., 2007). This multivariate model allows habitat analyses based on hydraulic analysis at HMUs, and the future application of specific tools that manage habitat indicators at the same scale, e.g. MesoHabsim (Parasiewicz, 2008).

The multivariate habitat suitability models for small and large fish were used to evaluate the dam operation effect on fish population, by comparing the habitat suitability for the fish under natural and regulated flow regimes, in the site more affected by regulation, $\mathrm{C} 5$. The watershed area and the mean annual flow are considerably smaller in the segments upstream, for this reason the use of a reference site upstream the dam was not considered. In addition, we evaluated the potential effects of two mitigation measures, i.e. two alternatives of environmental-friendly flow regimes. A 1dimentional hydraulic model was calibrated with the program RHYHABSIM (Jowett, 1999), based on the cross-sections and water surface elevation of the 3 field surveys in the simulation site. Ten evenly distributed flows were simulated based on rating curves, within the range of the hydraulic surveys.

At each flow, the number of fish was calculated with the habitat suitability model; hydraulic simulation provided the mean width, depth and substrate index by HMUs; backwaters and undercut banks were obtained from the field data by HMUs. The fish number was weighted by the area at each HMU and finally the total density of the site (number per meter of river length) was calculated; this value was used as an indicator of the habitat suitability for the fish. The curve of fish density versus flow was generated for small and large fish independently. The changes of slope in the curve of total density, as well as the total passage width (most limiting transect), were used to define a minimum environmental flow for Júcar nase, as indicated in the Spanish legal norm for hydrological planning (ARM/2656/2008). Then, the actual flow regime (regulated) was evaluated based on the fish density (habitat indicator), maximum average velocity in the site, and habitat connectivity. The actual regulated flow regime was estimated with monthly average flows of the last 10 years, 4 wet, 2 intermediate and 4 dry years (data provided by the Júcar River Basin Authority); the only data available for natural flow regime were measured in 1972, before the dam was built, they were used to define the pattern of natural regime, as explained below.

Two environmental-friendly flow regimes, as mitigation measures, were compared with the actual situation in the regulated site. The first one consisted of an environmental flow regime, with the same total water resources of the actual regulated regime (i.e., equal mean annual flow), and the 
monthly distribution proportional to the natural flow regime (natural flow pattern) during the months of natural high flows (January-April). The total amount of water resources was maintained for the two flow regimes, because that was considered a criteria of feasibility, to design a regime applicable by the water authorities.

The second regime was designed because for the large dam of Contreras, it is usually a priority to release the highest flows from April to September, what does not fit the natural flow regime. The flow release in such period is related to the irrigation of the orchards in the Valencian region, and the objective of getting minimum reservoir water levels in September, when the maximum flood risk occur in the region. Therefore, this regime was generated by combining environmental criteria with the water management, as follows: a) the same total flow of the actual regulated regime (same quantity of water resources), b) the minimum environmental flow determined previously for fish population enhancement, every month except during water release period, c) actual period of water release for irrigation, April-September, d) maximum mean flow imitating the natural timing, during the reproduction of the Júcar nase (April), followed by slow decrease proportional to natural regime until September, and e) during the release period, the mean water velocities in the study site should not be larger than $1 \mathrm{~m} / \mathrm{s}$ (upper water velocity limit for fry cyprinids, recommended in the Spanish legal norm for hydrological planning). This regime differs to the previous in a relevant aspect, the maximum release of water happens two months later than the natural regime, what potentially can affect the reproduction success of the Júcar nase.

\section{RESULTS}

The dendrogram showed that the classification of 8 sites was robust, meaning that the differences of habitat by HMUs were considerably larger among sites than it was within each site. Physical variability was also different among sites (Fig. 2a). In general the sites upstream of the large dam (C1 to $\mathrm{C} 4$ ) had a larger internal variability, i.e., less homogeneous or stable habitat characteristics than the sites downstream of the dam (C5 to C8), with regulated flow, except the site C5 (where approximately the same flow was found in the 3 surveys). Among the sites upstream, the MDS analysis (Fig. 2b) showed that the distances were large in comparison with the sites downstream. The site $\mathrm{C} 1$ was the most distinct among the 8 sites, according to the distances in the MDS.
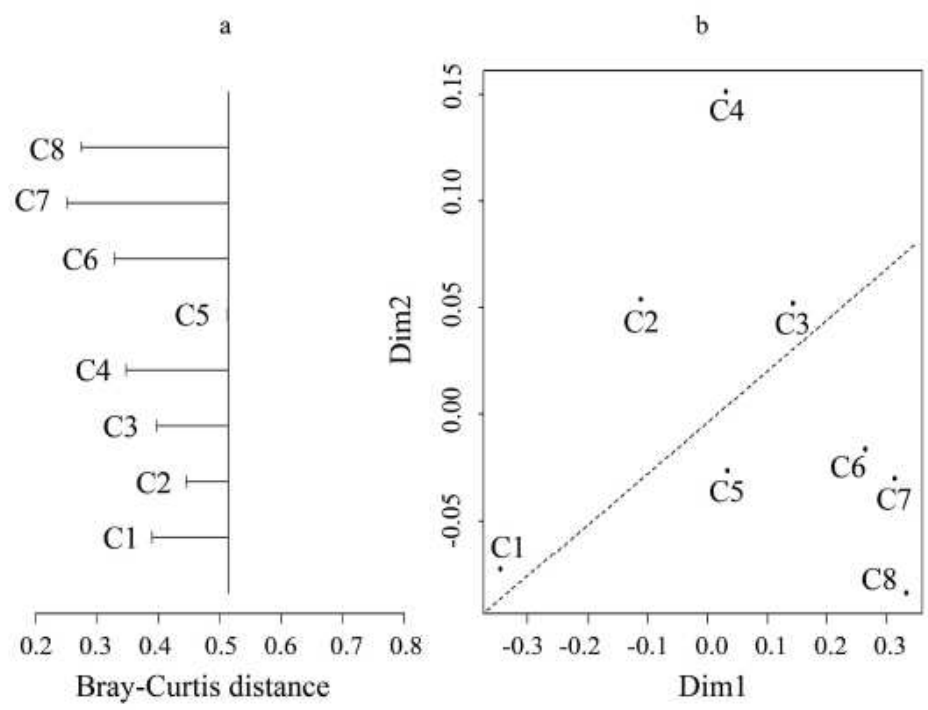

Figure 2. a) Dendogram to show the habitat variability of the 8 study sites (Bray-Curtis distance), from $\mathrm{C} 1$ (nearest to source) to $\mathrm{C} 8$ (lowest site). The average intra-qroup distances is represented by the end of the branch or horizontal line (Wi), while the inter-qroup distance (B) is represented by the base of the trunk or vertical line. b) Plot of the Metric Multidimensional Scaling (MDS) of the average distance to the 8 study sites. Dashed line separate requlated $(C 5-C 8)$ and not requlated sites (C1-C4). 
The box-plot indicated that the habitat type is very relevant for the abundance of Júcar nase, and that slow and deep habitats are the most suitable for the species. Relevant differences were not found in Júcar nase abundance between the upstream and downstream sites. However, a more detail analysis, comparing each HMU type, showed that relevant differences occurred in the pool $(p<$ $0.05)$, run $(p<0.01)$ and rapid $(p<0.05)$. However, the results for run and glide are unreliable because of the small number of both HMUs upstream and downstream respectively. Upstream, in C1 a high Júcar nase abundance was found in the unique run habitat registered in the 3 years while downstream pool is clearly the HMU with the highest abundance of Júcar nase.
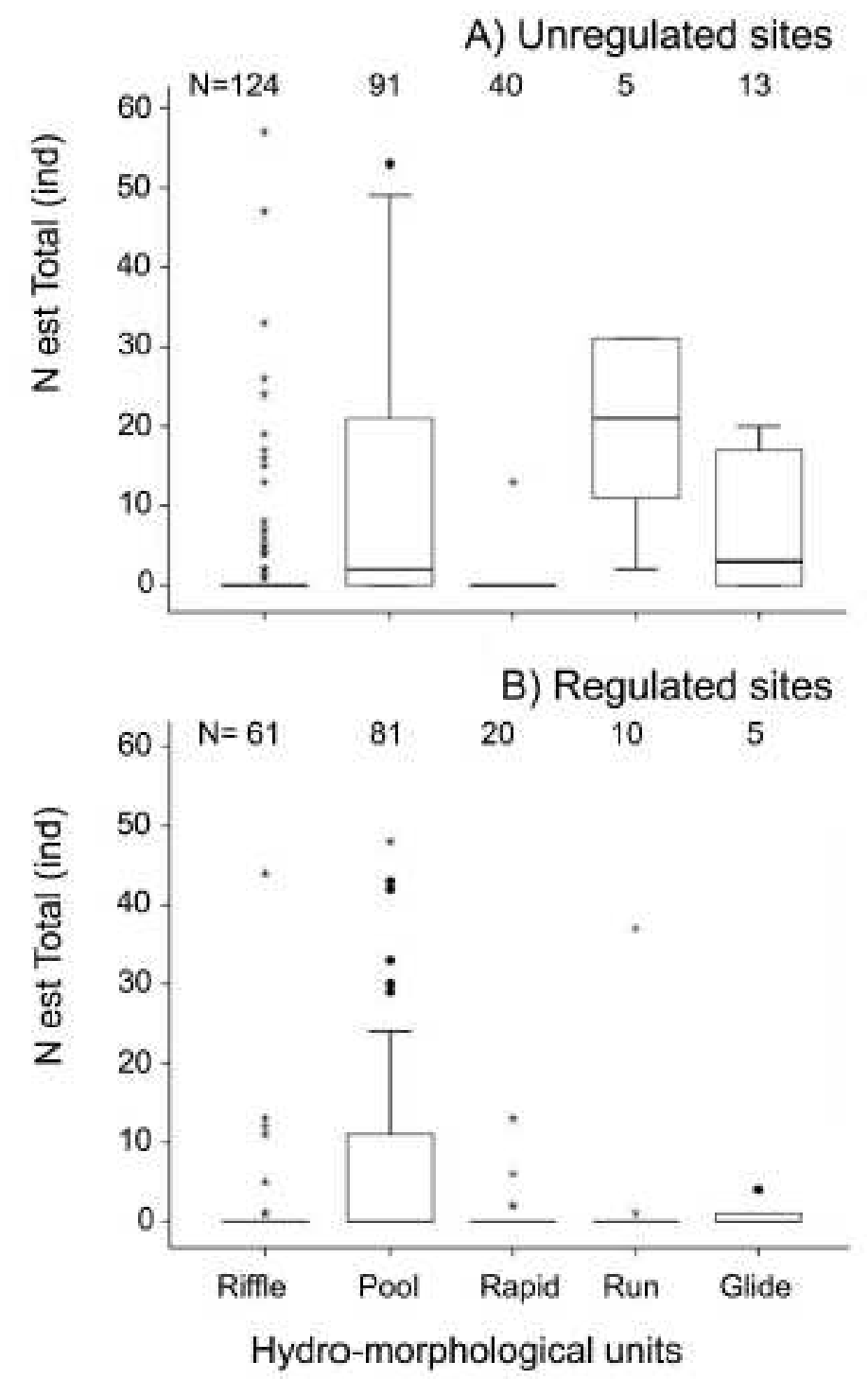

Fiqure 3. Comparison between Júcar nase estimation (summina adult and fry individuals) in the different hydro-morpholoqical units (P-pool; T-alide; C-riffle; R-rapid and Run) throuqh the A) unregulated sites ( $\mathrm{C} 1, \mathrm{C} 2, \mathrm{C} 3$ and $\mathrm{C} 4)$ and $\mathrm{B}$ ) regulated sites (C5, C6, C7, and $\mathrm{CB}$ ) obtained by MDS. For better visualization nine outliers (in the upstream sites $-\mathrm{C} 1+\mathrm{C} 2+\mathrm{C} 3+\mathrm{C} 4$ ) were removed from the box-plots. All data were used in the Mann-Whitney tests. $192 \times 309 \mathrm{~mm}(600 \times 600 \mathrm{DPI})$

In the sampling for microhabitat use, 54 independent data were recorded (48 of large, 6 of small fish), each one corresponding to one or more fish (schools). In total, 130 fish were observed (116 large, 14 small). Large and small Júcar nase selected optimal microhabitats with $0.75-1.25 \mathrm{~m}$ of depth, and water velocity between $0.5-0.14 \mathrm{~m} \mathrm{~s}^{-1}$ (Table 2). Among substrate types, silt and vegetation showed the highest suitability, and the best cover types were vegetation and woody 
debris. Microhabitat availability was recorded in 1059 points of the HMUs selected. The average conditions of depth ranged from the shallow waters of $\mathrm{C} 8(0.529 \mathrm{~m}$ of mean depth) to deeper habitats in $\mathrm{C} 7(0.807 \mathrm{~m})$; maximum depth indicated a wide range of habitat availability, varying from 1.27 to $2.1 \mathrm{~m}$ (Table 1). The mean water velocity varied from $0.247 \mathrm{~m} \mathrm{~s}^{-1}$ to $0.550 \mathrm{~ms}^{-1}$, and the maximum velocities registered were between 0.976 and $1.397 \mathrm{~ms}^{-1}$.

Table 1. Summary of microhabitat availability in the HMUs sampled for microhabitat use. The site codes identify the stream name and year of survey year. Hydro-morphological units (HMU) are P - Pool, Ra - Rapid, Ri - Riffle, Run, G- Glide.

\begin{tabular}{|c|c|c|c|c|}
\hline & \multicolumn{2}{|r|}{2006} & \multirow{2}{*}{$\begin{array}{c}2007 \\
\text { C6 } \\
\text { E1 Retorno }\end{array}$} & \multirow{2}{*}{$\begin{array}{c}2008 \\
\text { C6 } \\
\text { El Retorno }\end{array}$} \\
\hline & $\begin{array}{c}\text { C7 } \\
\text { Pelichan }\end{array}$ & $\begin{array}{c}\text { C8 } \\
\text { Casas del Río }\end{array}$ & & \\
\hline $\mathrm{N}^{\circ}$ records & 265 & 230 & 213 & 351 \\
\hline Mean depth (m) & $0.807 \pm 0.357$ & $0.529 \pm 0.308$ & $0.696 \pm 0.347$ & $0.837 \pm 0.498$ \\
\hline Maximum depth (m) & 1.66 & 1.27 & 1.52 & 2.1 \\
\hline $\begin{array}{l}\text { Mean water column } \\
\text { velocity }\left(\mathrm{m} \mathrm{s}^{-1}\right)\end{array}$ & $0.550 \pm 0.355$ & $0.247 \pm 0.242$ & $0.410 \pm 0.299$ & $0.351 \pm 0.271$ \\
\hline $\begin{array}{l}\text { Maximum water } \\
\text { column velocity }\left(\mathrm{m} \mathrm{s}^{-1}\right)\end{array}$ & 1.397 & 0.976 & 1.223 & 1.223 \\
\hline Dominant substrate & Fine gravel & Fine gravel & Cobbles & Fine gravel \\
\hline Dominant cover & No cover & No cover & No cover & No cover \\
\hline HMU types & $\mathrm{P}, \mathrm{Ri}$ & P, Ri, P, Ri & $\mathrm{P}, \mathrm{Ra}$ & G, P, Run, P, Ra \\
\hline
\end{tabular}

Before the GAM development with HMU's multivariate dataset $(\mathrm{N}=177)$, we observed that maximum depth, mean depth and mean velocity were correlated. Therefore, to avoid collinearity they were included separately in different models (trials), until the best calibrated model was found. The eight variables analysed were ordered by importance to fish abundance (see Table 3); but only six were in each trial as explained before. Both processes of variables selection (forward and backward) indicated that the model with the six variables including mean depth had the best performance, while avoiding collinearity. The adjusted $\mathrm{R}^{2}(\%)$ were 69.4 (small fish) and 72.4 (large), and the AIC were 394.7 and 959.3, respectively; all the variables included gave significant results of the F-ratio test $(\mathrm{P}<0.05)$. 
Table 2 Habitat suitability criteria (univariate curves) for depth (D, in $m$ ), mean water column velocity $\left(\mathrm{Vm}\right.$, in $\left.\mathrm{m} \mathrm{s}^{-1}\right)$, substrate ( $\mathrm{S}$ ) and cover (C) for the Júcar nase, developed in the river Cabriel. Suitability index is indicated for small (SIsmall) and large fish (Sladult).

\begin{tabular}{|c|c|c|c|}
\hline$\overline{\text { D }}$ & SIsmall & D & Sladult \\
\hline 0.00 & 0.0 & 0.00 & 0.0 \\
\hline 0,41 & 0.5 & 0,37 & 0.2 \\
\hline 0.61 & 0.8 & 0,56 & 0.5 \\
\hline 0.75 & 1.0 & 0,74 & 1.0 \\
\hline 1,00 & 1.0 & 0.93 & 1.0 \\
\hline 1.22 & 0.8 & 1.11 & 0.9 \\
\hline 1.42 & 0.7 & 1.30 & 0.6 \\
\hline 1,62 & 0.5 & 1.48 & 0.4 \\
\hline 1,82 & 0.2 & 1,67 & 0.3 \\
\hline$\overline{V m}$ & SIsmall & $\mathrm{Vm}$ & SIadult \\
\hline 0,000 & 0.4 & 0,000 & 0,0 \\
\hline 0.050 & 1.0 & 0.070 & 1.0 \\
\hline 0,100 & 1.0 & 0,140 & 0.9 \\
\hline 0.150 & 0.8 & 0.210 & 0.7 \\
\hline 0.190 & 0.6 & 0,280 & 0.5 \\
\hline 0.240 & 0.4 & 0.350 & 0.3 \\
\hline 0.290 & 0.3 & 0.400 & 0.2 \\
\hline 0,320 & 0.2 & & \\
\hline $\bar{S}$ & SIsmall & s & SIadult \\
\hline Vegetation & 1.0 & vegetation & 0.9 \\
\hline Silt & 0.9 & silt & 1.0 \\
\hline Sand & 0.7 & sand & 0.7 \\
\hline fine gravel & 0.5 & fine gravel & 0.5 \\
\hline Gravel & 0.5 & gravel & 0.5 \\
\hline Cobbles & 0.5 & cobbles & 0.5 \\
\hline Boulders & 0.5 & boulders & 0.5 \\
\hline large boulders & 0.5 & large boulders & 0.5 \\
\hline Bedrock & 0.5 & bedrock & 0.5 \\
\hline $\bar{C}$ & SIsmall & $\mathrm{C}$ & Sladult \\
\hline Without & 0.4 & without & 0.2 \\
\hline undercut banks & 0.5 & undercut banks & 0.5 \\
\hline Roots & 0.5 & Roots & 0.5 \\
\hline Boulders & 0.5 & boulders & 0.7 \\
\hline Vegetation & 1.0 & vegetation & 1.0 \\
\hline Shadow & 0,8 & shadow & 0.6 \\
\hline wood debris & 0,8 & wood debris & 1,0 \\
\hline Others & 0.8 & others & 0.8 \\
\hline
\end{tabular}


Table 3. Spearman's correlation rank between the variables used in the GAMs and the estimated numbers (N.est) of small and large Júcar nase by HMU (** $\mathrm{p}<0.05 ; * \mathrm{p}<0.01$ ).

\begin{tabular}{llll} 
Variables & $\begin{array}{l}\text { N.est } \\
\text { Adult }\end{array}$ & Variables & $\begin{array}{l}\text { N.est } \\
\text { Fry }\end{array}$ \\
\hline DepthMean & $.428^{* *}$ & DepthMean & $.418^{* *}$ \\
DepthMax & $.419^{* *}$ & DepthMax & $.415^{* *}$ \\
VelocMean & $-.364^{* *}$ & VelocMean & $-.368^{* *}$ \\
Undercut_Banks & $.354^{* *}$ & SubsIndex & $.275^{* *}$ \\
SubsIndex & $.309^{* *}$ & Undercut Banks & $.271^{*}$ \\
QuietWater by vegetation & $.216^{*}$ & QuietWater by vegetation & $.192^{*}$ \\
Flow & .103 & Flow & $.167^{*}$ \\
WidthMean & -.095 & PocketWater & -.120 \\
PocketWater & -.040 & WidthMean & -.049 \\
BackWater & -.032 & BackWater & .006 \\
\hline
\end{tabular}

Figures 4 and 5 represent how the Júcar nase abundance varies with the six variables selected. The mean depth is the only variable where the curve (both for small and large fish) do not show a clear maximum within the habitat conditions under study, but a continuous increase. This variable is the most relevant and positively related with abundance, together with maximum depth (Table 3 ). It is important to indicate that this variable was positively correlated with maximum depth, and negatively with mean velocity. Mean width was also related to abundance, but the Spearman's Rho did not show this relation; for small fish there is a range where it is not important (width smaller than $18 \mathrm{~m}$ ), but larger width is negative to the fish abundance. The curve of large fish shows a clear optimum around $17 \mathrm{~m}$ width. The substrate index have a strong relation with fish abundance (Table 3 ), and the curves indicate the same optimum for small and large fish, around 5, corresponding to gravel; the relation is positive, indicating that in general, the best HMUs have medium or large substrate sizes. The flow is related to abundance, depending on the fish size; while optimum for large fish is in medium flows around $4 \mathrm{~m}^{3} \mathrm{~s}^{-1}$, for large fish is around $5 \mathrm{~m}^{3} \mathrm{~s}^{-1}$. Backwaters shows an optimum for small and large fish, between 15 and $20 \mathrm{~m}^{2}$, and undercut banks have in general a positive influence, although there is a maximum between 60 and $80 \%$ of the habitat unit.
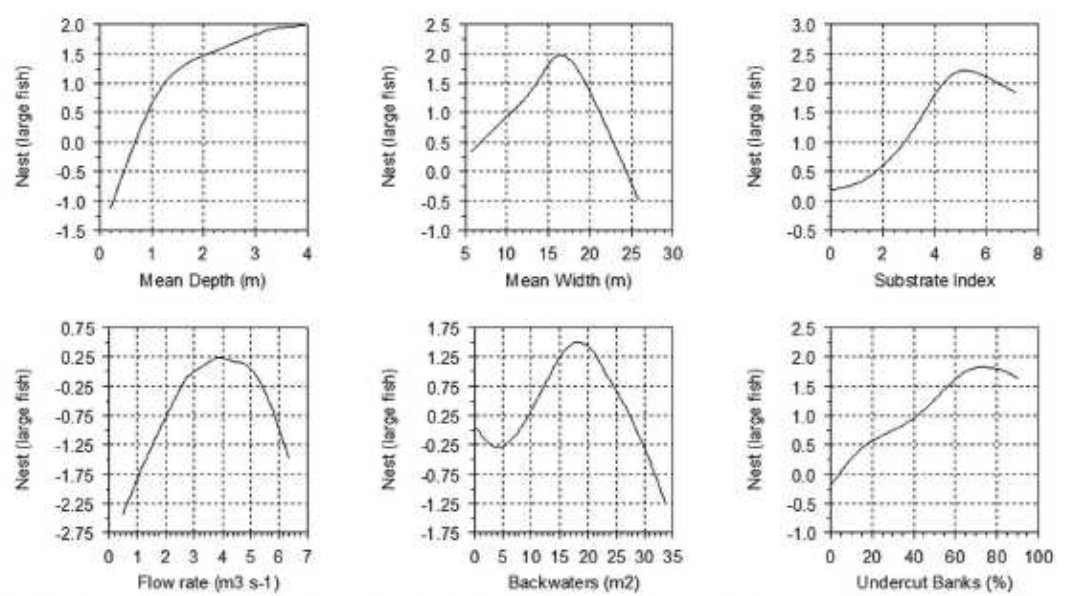

Figure 4. Adult Júcar nase (large fish) abundance prediction curves in function of mean depth, mean width, substrate index, flow rate, undercut banks and backwaters obtained with Generalized Additive Model (GAM) 

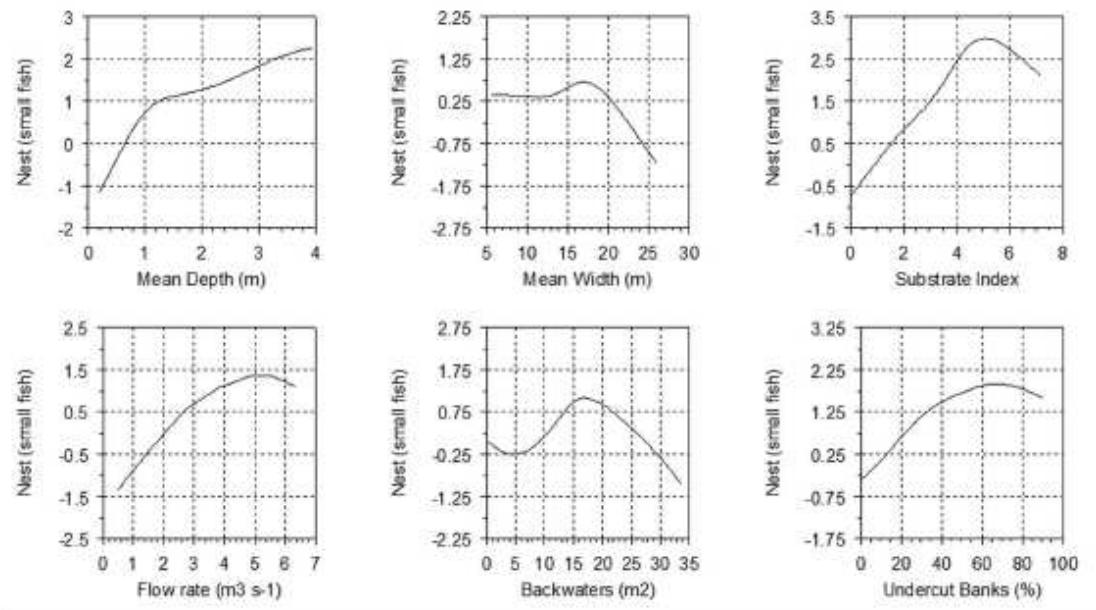

Figure 5. Fry Júcar nase (small fish) abundance prediction curves in function of mean depth, mean width, substrate index, flow rate, undercut banks and backwaters obtained with Generalized Additive Model (GAM).

In the hydraulic simulation, the flows ranged from the minimum calibration flow $\left(0.57 \mathrm{~m}^{3} \mathrm{~s}^{-1}\right)$ to the maximum $\left(13.93 \mathrm{~m}^{3} \mathrm{~s}^{-1}\right)$, and the ranges of hydraulic variables obtained were $4.74-30.89 \mathrm{~m}$ of mean width, 0.03-1.68 m of mean depth, and 1.2-7.3 of substrate index. The backwaters area by HMU had a small range of variability $\left(1-2.5 \mathrm{~m}^{2}\right)$, as well as the undercut banks $(0-7 \%)$. The fish density curves were constructed for small and large fish, and the total density indicated a minimum environmental flow (change of curve's slope) of $3.5 \mathrm{~m}^{3} \mathrm{~s}^{-1}$ (Fig. 6). Such flow provided river connectivity, with $3.5 \mathrm{~m}$ of total passage width, approximately $50 \%$ of the optimum value, which is acceptable for such purpose.
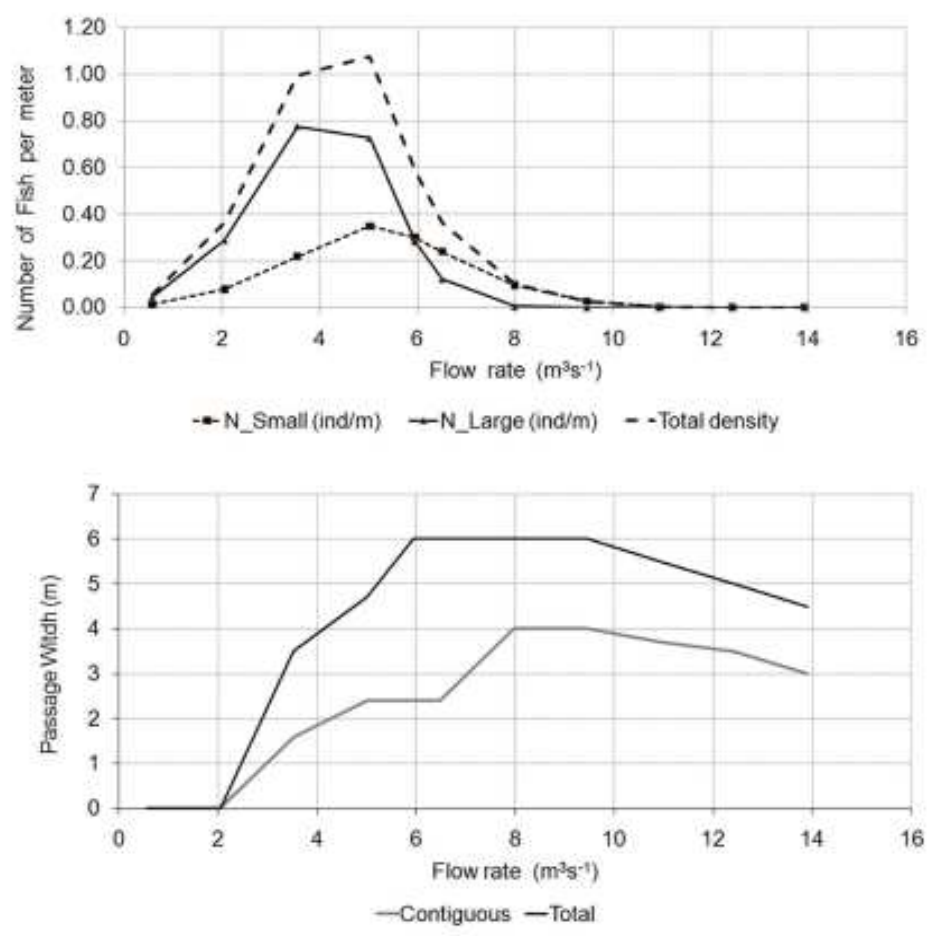

Fiqure 6. Number of adult and fry Júcar nase per meter estimation downstream the larqe dam of Contreras, Cabriel River and passage width curves, derived by physical habitat simulation from Rhyhabsim (Jowet, 1999). The river flows measured in the 3 field campaians were $0.577,5.957$ and $13.93 \mathrm{~m} 3 \mathrm{~s}-1$. "Contiguous" passage width was the minimum length of water surface along the transect where depth is larger than $0.25 \mathrm{~m}$ and mean velocity smaller than $1.25 \mathrm{~ms}-1$. The "Total" is the sum of lenqths in separated areas in the cross-section that meet that condition for passaqe (also in the transect with minimum value). 
The differences between the two regimes to evaluate (mitigation measures) are also observed in Fig. 7; while one is partially imitating the natural seasonality (in the months of larger natural flows) with maximum in February, the other has the maximum when the water administration release the water for irrigation (April), decreasing until the minimum flow is maintained, in September. The evaluated flow regimes had a total of water resources equal to the actual availability, equivalent to a mean annual flow of $\left(4.28 \mathrm{~m}^{3} \mathrm{~s}^{-1}\right)$. The minimum flow estimated in the actual regime (last decade) was $0.593 \mathrm{~m}^{3} \mathrm{~s}^{-1}$, considerably lower than the environmental flow estimated here; furthermore, the curves of connectivity (both contiguous and total) indicate a lack of connectivity for Júcar nase in the study site.

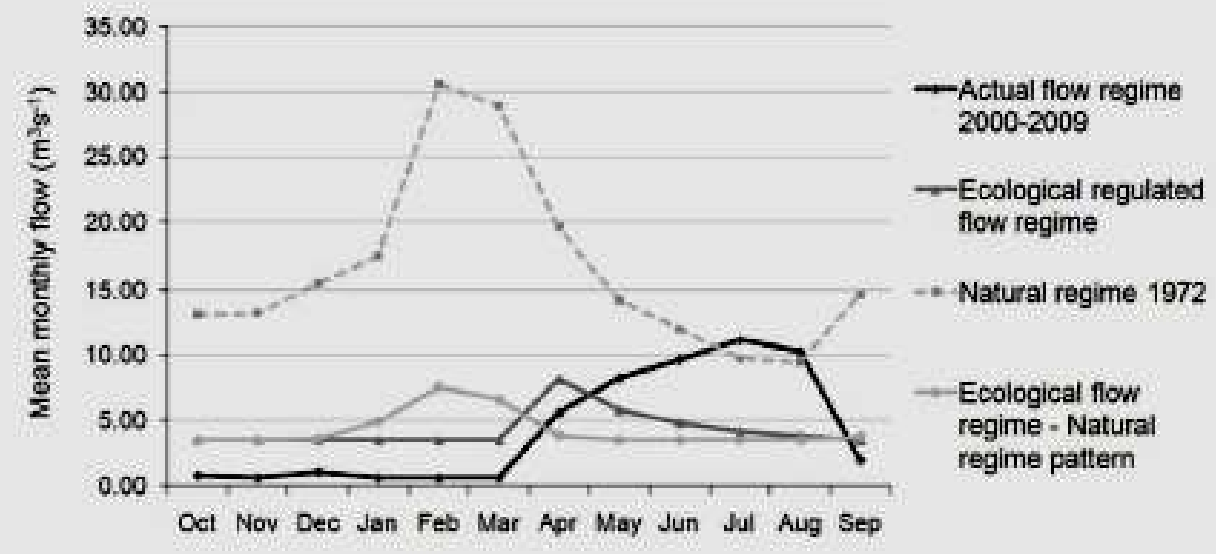

Fiqure 7. River flow reqimes evaluated in the study site, downstream the larqe dam of Contreras, in the Cabriel River. It is represented the actual requlated flow reqime (mean values of the last 10 vears), the proposal for environmental (ecoloqical) flow reqime with the same total flow release of the actual flow regime and with the same water release period (April - September), and the maximum mean flow in the reproduction period (April) and the environmental flow regime with the pattern of the natural flow regime (before the dam). The original data for natural flow regime $(1971-1972)$ is also shown. $49 \times 25 \mathrm{~mm}(600 \times 600 \mathrm{DPI})$

Fig. 8 shows the differences between the Júcar nase density in the four flow regimes studied. The natural regime used is biased because it only represented one wet year, comparing with the actual regime which was the average of 10 years, much more representative of real flow regime. The fish density curve obtained by habitat suitability model was simulated for a range of flows that barely contained flows as high as the ones in the natural regime. In fact, the minimum flows observed in natural regime in July $\left(9.7 \mathrm{~m}^{3} \mathrm{~s}^{-1}\right)$ and August $\left(9.4 \mathrm{~m}^{3} \mathrm{~s}^{-1}\right)$ were associated with very low fish densities (Fig. 8a). In the other hand, the fish densities of the environmental flow regimes were much higher (total density of $10 \mathrm{indm}^{-1}$ ) than the ones of the actual regime (total density of 1 indm $^{-}$ ${ }^{1}$ ). The fish density of both adult and fry individuals in the environmental flow regime with the same pattern of the natural regime, i.e. one maximum flow in February, revealed a stable monthly evolution until and after February. In this month both densities fell down to values lower than 0.2 indm $^{-1}$ (Fig. 8b). In the second environmental flow regime, with the same monthly flow pattern of the actual regime, occurred the same event with 2 months delay, i.e. the decrease occurred in April, a critical month for Júcar nase reproduction (Fig. 8c). 

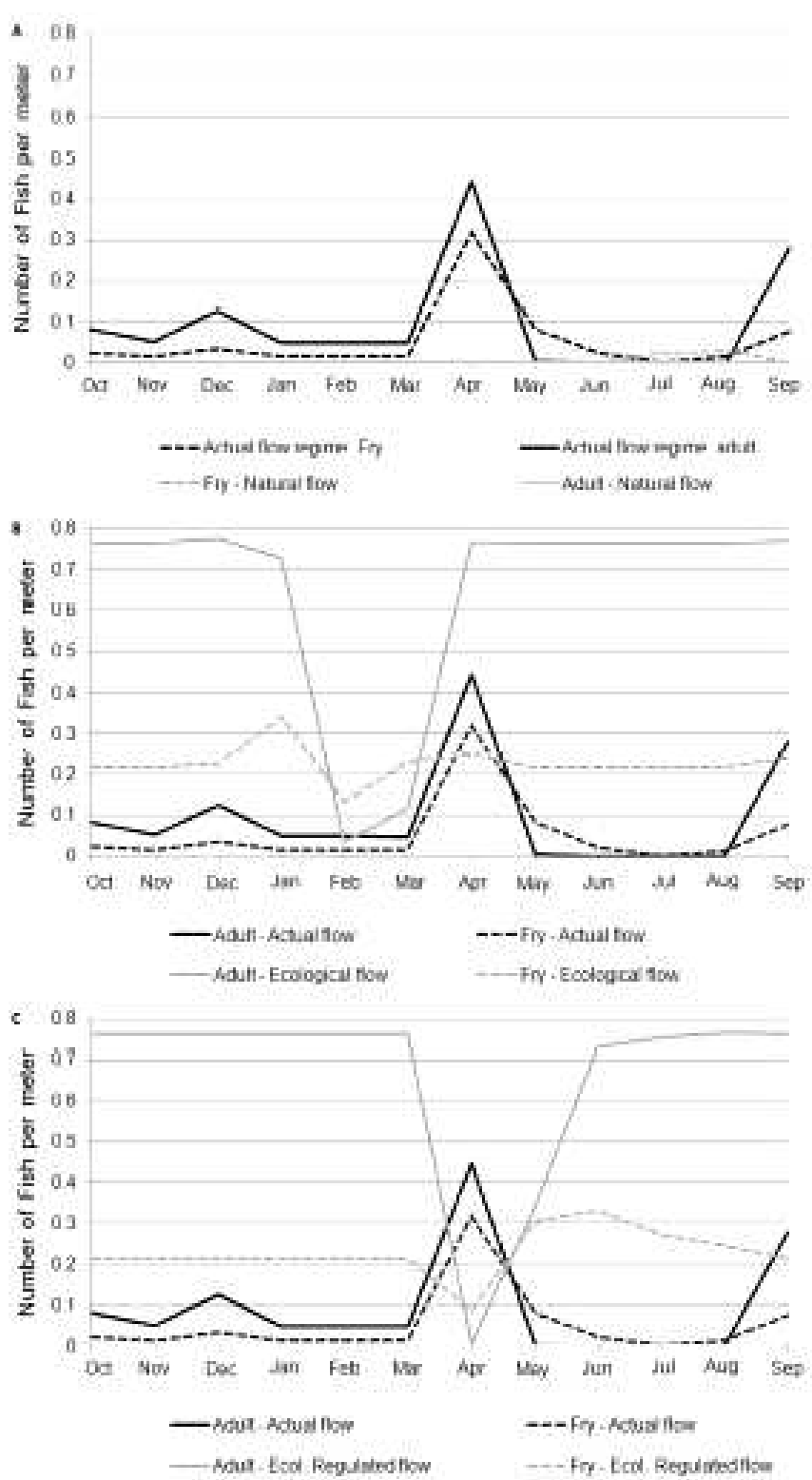

Fiqure 8. Comparative of Júcar nase density downstream the larqe dam of Contreras in Cabriel River from the actual requlated flow reqime $(2000-2009)$ and the A) natural flow reqime $(1972), B)$ the environmental flow regime (ecological flow) and C) one environmental flow regime more adequate with the management and human water requirements. $99 \times 180 \mathrm{~mm}(600 \times 600 \mathrm{DPI})$

\section{DISCUSSION}

The habitat comparison based on HMUs indicated that distances among the upstream sites, C1, C2, C3 and C4 were greater than among the regulated sites, downstream of the dam. Especially C1, with the smallest watershed area in the headwaters, is separated from other sites (Fig. 2); here the affection of the natural flow variability can be relevant, as it is characteristic in other Mediterranean rivers (Sabater et al., 1992). This fact is probably determining the habitat characteristics, making this site more different to the rest. It is well known that several years before the start of the study, the environmental administration had to rescue the fish populations by electrofishing because the channel was completely dry (information not published); therefore, the hydromorphological conditions are different in this aspect, what can be related to changes in the sediment transport. For example, $10 \%$ was the median percentage of silt in $\mathrm{C} 1$, versus $5 \%$ in the other sites together $(\mathrm{C} 2$, C3, C4), suggesting effects of sedimentation. In the 3 campaigns of study, C1 was never dry. 
Regarding habitat variability, the regulated site $\mathrm{C} 5$, below the dam, presented the highest variability during the study period, equivalent to the variability among sites (i.e., variability within the site $\bar{W}_{i}$

403 was approximately equal to $\bar{B}$ ). One possible reason is that the river passes through a very narrow area in a canyon where it is more confined laterally, which causes a larger variability of habitat characteristics before, within, and after the canyon, all in the study site C5. In spite of the variability, the MDS indicated that habitat characteristics of C5 are not very different of other regulated sites. During the three years of study the flows measured in C5 were similar (approximately $0.5 \mathrm{~m}^{3} \mathrm{~s}^{-1}$ ) due to the dam operation. In our opinion, the flow regulation causes the smaller differences among the sites downstream of the dam, diminishing the habitat diversity in space and time, as it was observed in other rivers in Spain (García de Jalón, 1987).

The differences of abundance among sites and HMU type's indicate a large variability in space, then the comparison of regulated $v s$. unregulated sites indicated no differences. However, with the test at more detail by HMU types, the test is more reliable and show differences in pool, rapid and run. The relations between habitat variables and fish abundance are discussed further in this article, based on the habitat suitability models, but other factors are interacting in these results. In the site with largest variability, C5, in theory the fish could find good habitats to live, but the abundance of the fish was very low or null (only a few individuals were observed once in a visit, not during the snorkelling counts). Therefore, other variables not assessed in this study are also relevant for the abundance and distribution of this endangered fish.

For example, water temperature plays a key role in stream ecosystem maintenance (Olivares, 2008), with effects on living organisms and on physicochemical processes which define the quality of the physical habitat. It is clear the importance of integrating water temperature in the physical habitat simulation and instream flow studies (Jowett, 1997; Bovee, 1998) especially when hydropower production is involved (Toffolon et al., 2010). The hydropower production at the dam of Contreras could influence Júcar nase distribution, through the water temperature. To minimize these impacts, Cushman (1985, in García et al., 2011) proposed three major areas of management: (i) structural changes with re-regulating dams, i.e. utilization of a small dam located downstream of a big one (operating with peaking flows), to stabilize flows downstream; (ii) habitat modification, i.e. manipulating river section to increase habitat availability (although this may reduce habitat diversity) and (iii) operational changes, i.e. to specify upper limits to the amount of variability of one or more characteristics of the flow released, like the change in discharge per unit time as a function of pre-existing discharge. A re-regulating small dam exist below Contreras, what can mitigate some of the level fluctuations in the river, but we hypothesize that water temperature can be more relevant. However, the analysis of temperature or hydropower production effect on Júcar nase distributions is part of a further research that is not in the scope of this article.

Habitat suitability criteria for Júcar nase considered the essential variables to perform the physical habitat simulation (Bovee, 1998). Many factors may affect the microhabitat use by the fish, like water temperature, habitat and food availability, light, turbidity, and species interactions (Baltz et al., 1982; Vondracek et al.,1992; Grossman and De Sostoa, 1994a,b; Santos et al., 2004). These physical and biological factors can also affect the transferability of the microhabitat results from one stream to others (Orth, 1987; Thomas and Bovee, 1993; Lamouroux et al., 1999). In this study, the surveys were restricted to clear waters and daylight hours, in segments of order 2 or 3 (after Strahler) upstream the dam, or 4 (downstream), which should be considered for the application of the results in other streams or rivers, within the geographical distribution of the target species. Little size-related differences were found in the microhabitat use for Júcar nase in the spring and summer period. Both adult and fry selected slow and relatively shallow waters with substrate of silt and vegetation, and cover of vegetation or woody debris. We considered that there was no bias related to limitation of microhabitats' availability, because wide ranges of depth (maximum $2.1 \mathrm{~m}$ ) and velocity (maximum $1.4 \mathrm{~ms}^{-1}$ ) were measured, taking into account that Júcar nase inhabits segments 
of order 2 to 4 . The smaller sample size for small fish, due to the scarcity of this endangered species, is an actual limitation in the study, which could be addressed with future field work. The habitat suitability curves can be useful to managers, in the application of conservation measures for critical habitats, to maintain and enhance the native fish populations in Mediterranean rivers, and to design more environmental friendly hydroelectric facilities. Such facilities have been encouraged with the legislation of some countries, for example with the European Water Framework Directive and the Clean Water Act in the United States (García et al., 2011).

The GAMs predicting fish density based on HMUs' variables during 3 years proved to be a suitable tool. Multivariate habitat suitability model made with GAMs can analyse non-linear relationships between species distribution and environmental variables, and take into account the correlation and interactions among variables (Ahmadi-Nedushan et al., 2006; Jowett et al., 2007). The variables integrating the best model provided good results as predictors of Júcar nase density. Some authors found that depth is a key variable in the microhabitat selection of other species in the taxonomic group of Chondrostoma (Copp, 1992; Martínez-Capel et al., 2009, Rincón et al., 1992; Grossman and De Sostoa 1994a, b). The results show that where depth increases and, consequently water velocity reduces, the abundance of Júcar nase raise (velocity was not in the model but it was correlated with mean and maximum depth). This is coherent with the relatively large abundance recorded in pools. The selection of deep waters in pools may suggest a relatively low swimming capacity of the Júcar nase, in relation to other cyprinids (personal underwater observation, which advise further research), and can be also related with the shelter against fast waters located in the banks of the pools (emergent vegetation, undercut banks), with the food availability and protection against predators (Martínez-Capel et al., 2009).

Other interesting outcome is the substrate and its relation with fish abundance. While at microhabitat scale the finer substrate is related with slow waters and cover (normally located in river banks and in areas with vegetation), at the HMUs scale, abundance of Júcar nase increase with medium-coarse substrate, like other fish species (Santos et al., 2004; Gosselin et al., 2010). This species feed mainly by scraping on periphyton, therefore medium and coarse substrate is positive for the feeding. A coincidence between microhabitat and HMU models is that undercut banks have a positive effect on Júcar nase habitat. These results indicate the positive feedback and the importance of complementing microhabitat with meso-scale studies, providing synergies for future applications in mitigation measures and species conservation. As some studies have remarked, the use of models based on multiple spatial scales outperform single-scale analyses (Olden et al., 2006), what suggest lines of future model developments for this endangered fish. "How much water does a river ecosystem need?' remains a challenging question that requires understanding of the direct and indirect interactions between flows and biota over time and space (Petts, 2009).

The differences between the natural flow regime and the actual regulated regime were noticeable; however, the lack of more data about the natural flow regime, before the dam construction (e.g. in dry and wet years) was a source of uncertainty in this analysis. The natural flow regime only represents one year, while the regulated flow regime represents the average of the last 10 years (4 wet, 2 intermediate and 4 dry years). In our opinion, the uncertainty in the natural flow regime is high and the data could fail in demonstrating the real natural regime in the river. This can be the reason to find better results (in estimated fish abundance) with the actual regulated regime. This problem suggest the possibility of correcting the total water resources in the regimes evaluated, to make a more reliable comparison, focused on the flow pattern and not in the total amount of water. For example, a synthetic annual hydrograph imitating the natural regime could be generated with the same seasonality (proportion of flow rate o mean annual flow), but with the mean annual flow determined in the regulated regime of the last decade. However, the actual flow regime seems to be inadequate to Júcar nase, because the actual minimum flow does not allow river connectivity, and the dam release is maximum from April to September. Therefore, while natural flow regime had the maximum flow in February and the minimum during the summer, in the regulated regime the 
maximum occurs during and after the period of fish hatching, which could produce negative effects; for example, the drag of nests and fry fish, and the consequent reduction in the recruitment (Humphies and Lake, 2000). It may also produce a temperature decrease in such period, influencing on fish growth (Cowx et al., 1989; Harby et al., 2009). However, the present analysis with habitat suitability models did not allow the evaluation of those effects.

The two flow regimes evaluated as mitigation measures produced an increase of the minimum flow in relation to the actual regime, approaching to a value more similar to other Mediterranean rivers. For example the river Segura in Spain, with a mean annual flow of $4.28 \mathrm{~m}^{3} \mathrm{~s}^{-1}$, required a minimum environmental flow of $4 \mathrm{~m}^{3} \mathrm{~s}^{-1}$ downstream a large dam (Segura River Basin Management Plan of 1998), in a heavily regulated basin (Belmar et al., in press), even though they were calculated taking into account the needs of water for irrigation and human consume.

The comparison of the mitigation measures indicated that, most of the time, the suitability of the flow rate for the Júcar nase as a whole (small+large fish) is ten times larger in the two regimes proposed, in relation to the actual flow regime. For both environmental-friendly regimes the total fish density is very similar (10 ind. per meter), but not the monthly variation. In the first environmental regime, fish density of small and large fish show a rapid fall in February, due to the maximum flow. These flows have a 'cleaning' effect on the river substrate (Naesje et al., 1995; Wesche et al., 1987) and the temperature decrease derived of these high flows have the effect of instigating the migration and reproduction of the cyprinids (Cowx et al., 1989; Harby et al., 2009). This flow regime with the same monthly evolution seems to be the best alternative. Although the second alternative can be considered an environmental-friendly regime, because it meets the basic recommendation of the minimum environmental flow, it shows the same monthly flow variation of the actual regulated regime, as well as the minimal estimated habitat suitability or fish density in April (both small and large fish), when the fish reproduction occurs. This indicates that, in less proportion than the actual regime, in this proposed environmental regime the drag of nests and fry fish, and the consequent reduction in the recruitment could degrade the fish population, as mentioned above. As a general comment for this analysis, the evaluation of the flow regimes with models based on hydromorphological units was useful, and the presentation of the models in this article provides the possibility of future evaluations with new mitigation measures.

The studies on habitat suitability criteria, considering different scales, are essential for the implementation of environmental flow regimes in regulated rivers, and for the conservation of endangered species with scarce information. This study indicates that the synergy of models at different scales can improve the comprehension of the interactions among fish and habitat features. Furthermore, in order to assess the effects of river regulation in the actual framework of European water management, it is very important to implement an eco-hydromorphological approach, integrating ecology (relations fish-habitat at the scale of microhabitat and hydromorphological units), hydrology and fluvial geomorphology (Vaughan et al., 2009).

\section{ACKNOWLEDGEMENTS}

This project was partially funded by the Spanish Government (Ministerio de Medio Ambiente y Rural y Marino - Confederación Hidrográfica del Júcar). We especially thank Matias Paredo for the cooperation in the field work and suggestions on data analysis, we also thank to Rafa Casas, Marta Bargay, Pau Lucio and other students that cooperated in the field work. Thanks to Colin Custard for the academic review of English. We also acknowledge the comments and suggestions of the reviewers on this paper. 
Ahmadi-Nedushan B, St-Hilaire A, Bérubé M, Robichaud E, Thiémonge N, Bobée B. 2006. A review of statistical methods for the evaluation of aquatic habitat suitability for instream flowassessment. River Research and Applications 22: 503-523.

Akaike, H. 1974. A New Look at Statistical-Model Identification. IEEE Transactions on Automatic Control 19(6): 716-723.

Baeza D, Martínez-Capel F, García de Jalón D. 2003. Variabilidad temporal de caudales: aplicación a la gestión de ríos regulados. Ingeniería del Agua 10: 469-478.

Baltz DM, Moyle PB, Knight NJ. 1982. Competitive interactions between benthic stream fishes, riffle sculpin (Cottus gulosus) and speckled dace (Rhinichthys osculus). Canadian Journal of Fish and Aquatic Sciences 39: 1502-1511.

Bisson JN, Usseglio-Polatera P, Thomas S, Moreteau JC. 1998. Stream community structure in relation to spatial variation: the influence of mesohabitat characteristics. Hydrobiologia 389:73-88.

Bovee KD. 1986. Development and evaluation of habitat suitability criteria for use in the Instream Flow Incremental Methodology. National Ecology Center, Division of Wildlife and Contaminant Research, Fish and Wildlife Service. Washington DC. Instream Flow Information Paper 21, Biological Report 86(7).

Bovee KD, Lamb BL, Bartholow JM, Stalnaker CB, Taylor J, Henriksen J. 1998. Stream habitat analysis using the instream flow incremental methodology. Biological Resources Division Information and Technology Report USGS/BRD-1998-0004. VIII. Fort Collins: U. S. Geological Survey, $131 \mathrm{pp}$.

Brainwood M, Burgin S, Byrne M. 2008. The impact of small and large impoundments on freshwater mussel distribution in the hawkesbury-nepean river, Southeastern Australia. River Research and Applications 24: 1325-1342.

Copp, GH 1992. Comparative microhabitat use of cyprinid larvae and juveniles in a lotic floodplain channel. Environmental Biology of Fishes 33: 181-193.

Costa R, Martínez-Capel F, Muñoz-Mas F, Alcaraz-Hernández JD, Hernández-Mascarell AB, Garófano-Gómez V. 2010. Relations between mesohabitat features and abundance of the endangered Júcar nase, in the Júcar River Basin, Spain. In Proceedings of the 8th International Symposium on Ecohydraulics. International Association of Hydraulic Engineering and Research (IAHR): Concepción, Chile; 894-899.

Cowx IG, Gould RA. 1989. Effects of stream regulation on Atlantic salmon Salmo salar L. and brown trout Salmo trutta L. in the upper Severn catchment, UK. Regulated Rivers: Research and Management 3: 235-245.

Doadrio I. 2001. Atlas y Libro Rojo de los Peces Continentales de España. Museo Nacional de Ciencias Naturales: Madrid; 233 pp.

Doadrio I. 2003. Atlas y Libro Rojo de los Peces. Dirección General de Conservación de la Naturaleza-CSIC: Madrid; 374 pp.

Dolloff CA, Hankin DG, Reeves GH. 1993. Basinwide estimation of habitat and fish populations in streams. U.S. Department of Agriculture. Forest Service. Southeastern Forest Experiment Station; $25 \mathrm{pp}$. 
Cushman RM. 1985. Review of ecological effects of rapidly varying flows downstream from hydroelectric facilities. North American Journal of Fisheries Management 5: 330-339.

Elvira B. 1995. Conservation status of endemás freswater fish in Spain. Biological Conservation 72: $129-136$.

Elvira B, Almodovar A. 2008. Threatened fishes of the world: Chondrostoma arrigonis (Steindachner, 1866) (Cyprinidae). Environmental Biology of Fishes 81(1): 27-28.

Ferreira T, Oliveira J, Caiola N, De Sostoa A, Casals F, Cortes R, Economou A, Zogaris S, GarcíaJalón D, Ilhéu M, Martínez-Capel F, Pont D, Rogers C, Prenda J. 2007. Ecological traits of fish assemblages from Mediterranean Europe and their responses to human disturbance. Fisheries Management and Ecology 14: 473-481.

Fette M, Weber C, Peter A, Wehrli B. 2007. Hydropower production and river rehabilitation: A case study on an alpine river. Environmental Modelling Assessment 12: 257-267.

Frissell CA, Liss WJ, Warren CE, Hurley MD. 1986. A hierarchical framework for stream habitat classification: Viewing streams in a watershed context. Environmental Management 10: 199-214.

García de Jalón D. 1987. River regulation in Spain. Regulated Rivers: Research \& Management 1: 343-348.

García A, Jorde K, Habit E, Caamaño D, Parra O. 2011. Downstream environmental effects of dam operations: changes in habitat quality for native fish species. River Research and Applications 27(3): 312-327.

Goslee SC, Urban DL. 2007. The ecodist Package for Dissimilarity-based Analysis of Ecological Data. Journal of Statistical Software 22 (7): 1-19.

Gosslin MP, Petts GE, Maddock IP. 2010. Mesohabitat use by bullhead (Cottus gobio). Hydrobiologia 652: 299-310.

Granado-Lorencio C. 1996. Ecología de Peces. Seville: Universidad de Sevilla; 353 pp.

Grossman GD, De Sostoa A. 1994a. Microhabitat use by fishes in the lower Rio Matarraña, Spain: 1984-1987. Ecology of Freshwater Fish 3: 123-136.

Grossman GD, De Sostoa A. 1994b. Microhabitat use by fishes in the upper Rio Matarraña, Spain: 1984-1987. Ecology of Freshwater Fish 3: 141-152.

Hankin DG, Reeves GH. 1988. Estimating total fish abundance and total habitat area in small streams based on visual estimation methods. Canadian Journal of Fisheries and Aquatic Sciences 45: $834-844$.

Harby A, Alfredsen K, Forseth T, Halleraker JH, Scheit T, Sunt H, Ugedal O. 2009. Integration of flow, habitat and temperature mitigation in regulated rivers. Proceedings of the 7th International Symposium on Ecohydraulics. Universidad de Concepción: Concepción.

Hawkins CP, Kershner JL, Bisson PA, Bryant MD, Decker LM, Gregory SV, McCullough DA, Overton CK, Reever GH, Steedman RJ, Young MK. 1993. A hierarchical approach to classifying stream habitat features. Fisheries 18: 3-12.

Heggenes J, Brabrand A, Saltveit SJ. 1990. A comparison of three different methods for studies of stream habitat use by brown trout and Atlantic salmon. Transactions of the American Fisheries Society 119: 101-111. 
Hill G, Maddock I, Bickerton M. 2008. River habitat mapping: are surface flow type habitats biologically distinct? BHS $10^{\text {th }}$ National Hydrology Symposium, Exeter.

Humphries P, Lake, PS. 2000. Fish larvae and the management of regulated rivers. Regulated Rivers: Research and Management 16: 421-432.

Jowett IG. 1999. RHYHABSIM River hydraulics and Habitat Simulation. Version 5.0.

Jowett IG. 1997. Instream flow methods: A comparison of approaches. Regulated Rivers-Research \& Management 13(2): 115-127.

Jowett IG, Davey AJH. 2007. A comparison of composite habitat suitability indices and generalized additive models of invertebrate abundance and fish presence-habitat availability. Transactions of the American Fisheries Society 136: 428-444.

Jungwirth M, Muhar S, Schmutz S. 2000. Fundamentals of fish ecological integrity and their relation to the extended serial discontinuity concept. Hydrobiologia 422/423: 85 -97.

Lamouroux N, Capra H, Pouilly M, Souchon Y. 1999. Fish habitat preferences in large streams of southern France. Freswater Biology 42: 673-687.

Magalhães MF, Beja P, Canas C, Collares-Pereira MJ. 2002. Functional heterogeneity of dryseason fish refugia across a Mediterranean catchment: the role of habitat and predation. Freshwater Biology 47: 1919-1934.

Martínez-Capel F, García de Jalón D, Werenitzky D, Baeza D, Rodilla-Alamá M. 2009. Microhabitat use by three endemic Iberian cyprinids in Mediterranean rivers (Tagus River Basin, Spain). Fisheries Management and Ecology 16: 52-60.

Mouton AM, Alcaraz-Hernández JD, De Baets B, Goethals PLM, Martínez-Capel F. 2011. Datadriven fuzzy habitat suitability models for brown trout in Spanish Mediterranean rivers. Environmental Modelling \& Software 26: 615-622.

Naesje T, Jonsson B, Skurdal J. 1995. Spring Flood: A Primary Cue for Hatching of River Spawning Coregoninae. Canadian Journal of Fisheries and Aquatic Sciences. 52: 2190-2196.

Olden J, Poff N, Bledsoe B. 2006. Incorporating ecological knowledge into ecoinformatics: An example of modeling hierarchically structured aquatic communities with neural networks. Ecological Informatics 1: 33-42.

Olivares MA. 2008. Optimal hydropower reservoir operation with environmental requirements. Dissertation for the degree of Doctor of Philosophy in Civil and Environmental Engineering, University of California: California; 109 pp.

Orth DJ. 1987. Ecological considerations in the development and application of instream flow habitat models. Regulated Rivers: Research and Management 1(2): 171-181.

Parasiewicz P. 2008. Application of MesoHABSIM and target fish community approaches to restoration of the Quinebaug River, Connecticut and Massachusetts, USA. River Research and Applications 24(4): 459-471.

Petts GE, Maddock I. 1996. Flow Allocation for In-River Needs. In: The Rivers Handbook, 2, Calow P, Petts GE (Editors). Blackwell Scientific Publications: Oxford; 289-307.

Petts GE, Bickerton MA, Crawford C, Lerner DN, Evans D. 1999. Flow management to sustain groundwater-dominated stream ecosystems. Hydrological Process 13: 49-513. 
Petts GE. 2009. Instream flow science for sustainable river management. Journal of the American Water Resources Association 45(5):1071-1086.

$\mathrm{R}$ Development Core Team. 2008. $R$ : A language and environment for statistical computing. $\mathrm{R}$ Foundation for Statistical Computing, Viena, Austria. ISBN 3-900051-07-0, URL http://www.Rproject.org.

Rincón PA, Barrachina P, Bernat Y. 1992. Microhabitat use by 0+ juvenile cyprinids during summer in a Mediterranean river. Archiv für Hydrobiologie 125: 323-337.

Robson DS, Whitlock JH. 1964. Estimation of a truncation point. Biometrika 51:33-39.

Sabater S, Guasch H, Martí E, Armengol J, Vila M, Sabater F. 1992. The Ter, a Mediterranean river systems in Spain. Limnetica 8: 141-149.

Santos JM, Godinho FN, Ferreira MT. 2004. Microhabitat use by Iberian nase Chondrostoma polylepis and Iberian chub Squalius carolitertii in three small streams, north-west Portugal. Ecology of Freshwater Fish 13: 223-230.

Schiemer F, Keckeis H, Kamler E. 2003. The early life history stages of riverine fish: ecophysiological and environmental bottlenecks. Comparative Biochemistry and Physiology A133: $439-449$.

Schwartz JS, Herricks EE. 2008. Fish use of ecohydraulic-based mesohabitat units in a low-gradient Illinois stream: implications for stream restoration. Aquatic Conservation: Marine and Freshwater Ecosystems 18: 852-866.

Smokorowski KE, Pratt TC. 2007. Effect of a change in physical structure and cover on fish and fish habitat in freshwater ecosystems - a review and meta-analysis. Environmental Reviews 15: 15 41 .

Snelder T, Lehmann A, Lamouroux N, Leathwick J, Allenbach K. 2009. Strong influence of variable treatment on the performance of numerically defined ecological regions. Environmental Management, 44: 658-670.

Thomas JA, Bovee KD. 1993. Application and testing of a procedure to evaluate transferability of habitat suitability criteria. Regulated Rivers: Research and Management 8: 285-294.

Thomson JR, Taylor MP, Brierley GJ. 2004. Are river styles ecologically meaningful? A test of the ecological significance of a geomorphic river characterization scheme. Aquatic Conservation: Marine and Freshwater Ecosystems 14: 25-48.

Toffolon M, Siviglia A, Zolezzi G. 2010. Thermal wave dynamics in rivers affected by hydropeaking. Water Resources Research, VOL 46. W08536, DOI: 10.1029/2009WR008234, 2010.

Van Sickle J. 1997. Using mean similarity dendrograms to evaluate classifications. Journal of Agricultural, Biological, and Environmental Statistics 2:370-388.

Vaughan IP, Diamond M, Gurnell AM, Hall KA, Jenkins A, Milner NJ, Naylor LA, Sear DA, Woodward G, Ormerod SJ. 2009. Integrating ecology with hydromorphology: a priority for river science and management. Aquatic Conservation: Marine and Freshwater Ecosystems 19: 113-125.

Vidal-Abarca MR, Suárez ML, Ramírez-Díaz L. 1992. Ecology of Spanish semiarid streams. Limnetica 8: 151-160. 
707 Vondracek B, Spence B, Longanecker DR. 1992. Seasonal habitat selection of rainbow trout. 708 Report 009.4-91.9. Pacific Gas and Electric Company, Department of Research and Development: 709 San Ramon.

710 Wang L, Seelbach PW, Hughes RM. 2006. Introduction to landscape influences on stream habitats 711 and biological assemblages. American Fisheries Society Symposium 48: 1-23.

712 Wesche TA, Hasfurther VR, Skinner QD. 1987. Recommendation and evaluation of a mitigative 713 flushing flow regime below a high mountain diversion. In Symposium Proceedings, Water 714 Resources Related to Mining and Energy: Preparing for the Future, American Water Resources 715 Association, November 1-6, Salt Lake City, Utah. 18 pp.

716 Zimmerman JKH, Letcher BH, Nislow KH, Lutz KA, Magilligan FJ. 2009. Determining the effects 717 of dams on subdaily variation in river flows at a whole-basin scale. River Research and 718 Applications 26(10): 1246-1260. 